\title{
Managing ICT Based Service Innovation Projects
}

\author{
SANJA P. MARINKOVIĆ, University of Belgrade, \\ Faculty of Organizational Sciences, Belgrade \\ MAJA I. LEVI JAKŠIĆ, University of Belgrade, \\ Faculty of Organizational Sciences, Belgrade \\ JOVANA Đ. RAKIĆEVIĆ, University of Belgrade, \\ Faculty of Organizational Sciences, Belgrade
}

\begin{abstract}
Service innovation projects in which novelty is based on introduction of modern ICT usually imply cooperation between multiple parties and organizations. Recognizing the specific features of service innovation projects, this paper presents the results of case study research of four innovation projects conducted in Serbia. The features and duration of projects' phases were compared and analyzed. Simultaneity in implementation of the same phases has been found in all cases. Regarding management, defining user requirements and translating them into project requirements have been found as the most critical phases. It was confirmed that in case of innovation projects, managers' focus was on interactions and networking, with a significant degree of freedom and creativity.
\end{abstract}

Key words: new service development, innovation project, information and communications technology

\section{INTRODUCTION}

Service innovations are defined as introduction of new services to the market and significant improvement of the existing ones. Modern information and communications technology (ICT) enables more efficient and effective approaches in providing existing services and the emergence of entirely new services in different industries. The innovation process is a set of related activities that lead to only one innovation or to more interconnected innovations.

Similarly to innovation process, we can define the innovation project. Innovation project is a special set of activities that lead to the realization of certain innovation [1]. Definition of innovation project can be taken from the generally accepted definition by which the project is seen as a "complex unique business venture that is undertaken in the future in order to achieve goals within the projected time and costs" [2].

New service development processes (NSD), espe-

Author's address: PhD . Sanja Marinković, University of Belgrade; Faculty of Organizational Sciences, Belgrade, Jove Ilića 154

Paper received: 26.02.2014.

Paper accepted: 27.03.2014. cially when the novelty is based on the introduction of modern ICT, are usually realized in practice as innovation projects that involve cooperation between multiple parties and/or organizations. NSD as a project in the modern economy requires a wide range of technological expertise that is very often above the expertise level of service providers. Therefore, it increasingly implies connections, linkages, cooperation of several organizations with specific roles in differrent project stages [3]. These projects have to be managed having in mind their complexity and unpredictable nature.

\section{NEW SERVICE DEVELOPMENT PROCESS}

Innovation process usually begins by observing certain needs and generating ideas on how needs can be satisfied. Identified problems in existing processes can be impulse for generating ideas. The initial phases of development, related to needs and problem description, generating ideas and defining concepts are of crucial importance for the success of the next phases of NSD [4]. Collected ideas go through selection process taking into account various criteria such as feasibility and potential profitability.

Through the next steps, NSD projects are characterized by specific features that distinguish them 
from new product development (NPD) projects [5]. Raw materials are rarely used, while tools and equipment can be used is small extent. The output of the design process is a concept and process description. Service design may be based on standards, but they are usually few, and deviations from standard can be a part of the process and do not necessarily make unwanted consequences.

Services can be tested through a test run, through imitation of the procedure, but each performance will be different when being tested and in actual implementation, due to the presence of different clients and service providers. One of the important differences between NPD and NSD is that in the case of products, as design progresses, the changes are becoming increasingly expensive. This is usually expressed in $85 / 15$ rule, which indicates that approximately 85 percent of the costs of the product are determined by the decisions made in the first 15 percent of the design process. In the case of services, the design is not strict and rigid document, modifications and adaptations are possible and sometimes desirable in order to meet the wide variety of demands and client needs. These changes are usually not as expensive as in the case of products. However, this can bring the risk that the accumulation of unplanned changes that occur over time can result in decline of the quality and value of services [6].

There is a significant interaction between NSD process and service delivery. Their connection is more intense than in the case of NPD and production processes. Projects dealing with NSD require integration between needs of new service operations and process with the needs of current operations. It is believed that the compatibility between new service and current system is more important than in case of production.

This means that front and back office must work integrated to overcome their differences in goals and differences in time horizon. Activities such as communication, coordination and conflict management are identified as fundamental and critical, particularly in the case of NSD projects [7].

Comparison of NPD and NSD recognize the important roles of user, service provider staff, as well as less standardization in NSD projects [4]. NSD is cooperative, interactive process that is not strictly formalized, and includes participants from different parts of the company, but also from the external sources. Stakeholders may also play a significant role in a variety of ways and can be included in the innovation process [8]. Customers can have a significant role in service innovation process. They can be involved in different parts of the process, from idea generation and selection, through concept development, testing and commercialization.

\section{ICT AND SERVICE INNOVATION}

The development of ICT brought a changed and more intensive provider - user interactions. Internet has led to the emergence of new forms of communication, form text exchange (SMS, e-mail) to video conferencing. New forms of communication and interactions are continuously developing. Their implementation is overcoming time and space barriers.

The service feature that is especially evident when analyzing ICT based service innovation is that creating and consuming services are carried out at the same time. The introduction of ICT reduces the need for direct interaction of service providing staff and the client. The quality of services is affected by the quality of these interactions (direct or indirect).

ICT based service innovations are one of the most important areas of global competition. This can be seen from widely known examples in different fields, such as [9]: search engines (Google), auctions (eBay), games (World of Warcraft), music (iPod), and travel services (Hotels.com). According to Bygstad [9] these innovations have rarely occurred spontaneously, they need infrastructure for innovation, as evidenced by Google in which scalable infrastructure enables faster flow of product development. The balance between infrastructure and innovation is needed.

Management of NSD projects must keep track of effectiveness and efficiency of new services. Service development process must be shortened, having in focus the service quality and user needs and expectations. Taking into account the dynamics of the ICT, the speed in service innovation process, i.e. shortening the innovation process, is emerging as one of the key demands. Very often there is a pressure to enter the market before the competition and certain phases of innovation process should be handled in a limited period of time. In some cases, the individual phases shall be omitted. That is usually the case with traditional market research at the beginning and at the end of the process, i.e. before the launch phase.

When it comes to testing, Kuusisto [10] has identified two approaches of customer involvement. According to one, development of new services is firstly conducted by innovating firm and pilot customers are seen as those who evaluate the service and provide feedback for further specifications. In the second approach, the development and testing will coincide with providing the service. "In case of ICT services, concrete work input from customers was needed in development: detailed requirements have to be captured form customers and ultimately customers have to test 
the service - either explicitly (when errors or mismatches are found) or implicitly (when things run smoothly for the first time in real life)" [10].

Research results confirm the findings of Gago, and Rubalcaba [11] that ICTs play an important role in enabling business innovation. As stated by Evangelista and Sweeney [12] ICT plays a special role in customizing services and a special attention should be paid to factors influencing ICT adoption.

\section{SERVICE INNOVATION PROJECTS}

Development of new products and processes to the mid nineties in most of the companies was based on sequential development. The process consisted of a number decision-making points in which managers made decisions whether to move to the next phase, to go back to previous stage for revision, or to stop the project.

Organizations that were faced with the shortcomings and problems of the sequential approach to development exceeded to partially parallel model of development process [13]. Later, the model of concurrent engineering appeared, that was supposed to enable organizations to shorten the development process and avoid costly and lengthy iterations among the development phases. Simultaneous engineering is the development model in which some or all of development activities are at least partly overlapping. Although there is not enough empirical support for claims about connection among development speed and competitive advantage, many benefits arise as a result of shortening of development process, especially in very competitive markets [14].

Shortening the development time, or enter the market before competition, can bring benefits such as increased profitability by extending the life cycle of the product, the ability to dictate the prices and benefits related to development and production costs. In markets that are developing fast with short life product and process cycles, development speed and shortening the innovation process are necessary. Such markets are the ICT market, and markets of products and services, that are rapidly developing based on ICT implementation.

It has been shown that parallel activities and partially overlapped phases of the innovation process could bring benefits, but it should also be noted that in certain situations, simultaneous models can increase the risk or cost of development process. The model that seeks to minimize these risks is the Stagegate model developed by Cooper [15]. Key activities are identified and grouped into stages, and as a result many activities at every stage are taking place at the same time. Stage-gate model involves parallel pro- cessing, as opposed to sequential. Stage-gate model, from its inception to the present, has experienced significant changes, primarily due to increasing use of new technologies and the internet in the innovation process [16].

Management of innovation projects in organization is based on a clearly defined innovation process with recognized phases and key operations. In this way, it is possible to define the needed investments and to allocate the resources in different stages: human, material, financial. This is also important for setting timelines and outcomes that are clearly linked to a particular phase. Financing the innovation projects, whether from internal or external sources, is usually supported by a clear study that will be presented to potential investors. The study covers a detailed overview of all the necessary investments, with a projected income of innovation activities. It is the basis for the decisions related to investments. Consent and support of the management in innovating organization is needed, as well as the interest of external investors in innovation project. This process involves a detailed analysis of planned investments to review and evaluate all the risks connected to the project.

Managing innovation projects includes planning, implementation and control of all phases of innovation process in accordance with set targets, but is specific to a few key aspects [17]:

- innovation projects often start with poorly defined, sometimes very ambitious goals that develop and become clearer during the project conduction;

- innovation processes are of experimental and exploratory character and rarely follow a strict linear path;

- project teams are typically made up of experts from various fields with a strong degree of mutual trust; innovation projects are characterized by uncertainty and high degree of risk of failure;

- project teams are actively involved in risk management and achieve high level of flexibility and responsiveness by constantly seeking for new options;

- innovation projects need to be "sold" to the project sponsors and financiers.

The innovation processes are characterized by uncertainty and seemingly random nature, but it is still possible to find a basic form of success. The fact is that many innovation projects result in failure, but some of them make a huge success and profit to organizations and individuals. Regarding NSD project management, it was shown that successful ICT based service innovations were not a result of strict guiding of the project (focused on costs, time and quality) or 
of professional project managers. A negative relationship is found between flexible project planning and innovation project performance, whereas flexible product specifications are found to contribute positively [18]. Successful service innovation projects were present if there was a strong integration among service provider and external service users [9].

Innovation success depends on two key elements: the organization's resources (people, knowledge, equipment, money) and the organization's ability to manage them. Analysis of the economic effects of innovation activity involves analysis of the costs and revenues of the innovation process and precise identification of its key stages [17]. Cost Analysis of individual phase allows adequate planning, as well as reducing the risk of unforeseen events. In real life, phases of the innovation process overlap and occur simultaneously, including cooperation of several organizations. This makes the cost analysis for individual phases more complicate.

The innovation projects that do not generate the expected profits in a given period can be seen as important for long-term success and competitiveness of the organization. Strict criteria of economic efficiency should consider together with the analysis of their contribution to the organization's strategic directions [17]. All positive effects could go beyond the economic short-term unprofitable innovation project. Since the services should meet the needs of customers and preserve the competitive position, it is particularly important to include non-economic indicators for the evaluation and cost analysis of innovation projects. These indicators could be related to: development of innovative environment and innovative culture, enhancing creative potential, and strengthening cooperative competences.

\section{RESEARCH METHOD}

Existing theories and understanding of NSD processes are not adequate [19], although service innovations represent the key drivers of competitive advantage in different industries. In order to expand the knowledge in this area, this paper presents the results of research in the Serbian market. Four innovation projects were analyzed through case study method. The case study method is recommended as adequate when there is little or no available empirical research relating to a particular topic, i.e. when the survey is exploratory [20], [14], [21].

The unit of the analysis was innovation project that met the following: the project was implemented in service industry, it implied the involvement of several organizations, development and application of modern ICT was the base for service innovation, ICT development was conducted through outsourcing. The four selected projects represented me-too innovations, i.e. services that were already present in developed countries, but they were new to Serbian market. Open-source models and imitation strategy were used as a response to innovations that have already been introduced in the environment. Increased global nature of telecommunications made the ideas quickly spread on the market. Imitation and adaptation of successful products and services have become universally recognized innovation strategies [14]. The study was conducted through detailed documentation review for selected projects and structured interviews with project managers.

The projects selected for the study were:

1. Development of teletext

The project referred to development of a service provided by broadcasting companies which allowed searching information of different types (national, international and sport news, weather, TV programs, etc.). Project participants were: leading TV station, leading sports betting firm, small software developpment firm, and small hardware development firm.

\section{Development of traffic cadastre}

The project was related to introduction of modern ICT in the process of recording, monitoring and maintenance of traffic signals. It implied development of a system for accurately recording and tracking maintenance actions, their geo- positioning with visuals and proposing necessary actions. Project participants were: City Department of Transportation, small software and hardware development firm.

\section{Development of live betting}

The project was directed to development of a system could provide real-time insight into the games, in order to determine the preferences of players and thus calibrating the offer. The system had to display real-time statistics, the results and costs of all games. It should enable real-time control of 200 bookmakers present in different parts of the world, from one place, in order to reduce costs. Project participants were: leading sports betting firm, small software and hardware development firm.

4. Development of mobile marketing via Bluetooth technology

The project referred to development of a system for mobile marketing. It is a new form of advertising that enables the user of mobile portal to learn more about a particular topic or request any other service. Bluetooth technology through wireless data transmission should enable simpler and stronger connections among providers and users. Project participants were: leading mobile operator and small software and hardware development firm. 


\section{RESULTS AND DISCUSSION}

Comparison of selected service innovation projects was done through all stages of innovation process. Based on the document analysis and managers' responses and comments in the interviews, it was concluded that there was many simultaneous activities in all projects. Considering the duration of the phases, it was noted that there were significant differences among them. Time dynamics was analyzed through Gantt charts. Figure 1 presents a Gantt chart for teletext development project [22].

The analysis of Gantt charts for all four projects has shown simultaneity of the same phases. Based on these findings, the groups of simultaneous activities could be identified. The first group comprises: generating and selecting ideas, and external analysis in terms of selected ideas. Second group comprises: defining user requirements and translating them into project requirements.

The next group of activities refers to system development and testing, followed by the activities that are dealing with employee training in service providing organization, pilot and market testing.

The last group comprise launching and comercialization, end-user training and after launch services.

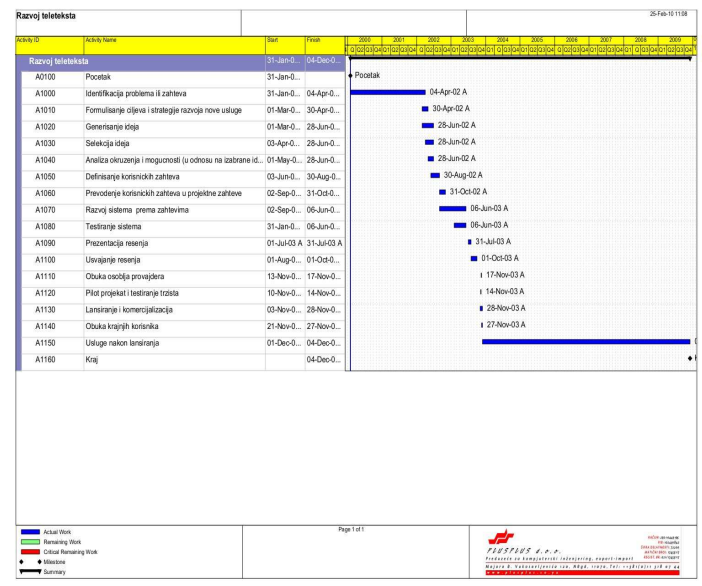

Figure 1 - Gantt chart for NSD project - Teletext

The observed overlapping and grouping of activeties, as well as many feedback loops that occur within the group should be taken into consideration in order to improve management actions. Primarily, it is important to note the duration of certain groups of activities. One of the approaches to measure NSD success related to time dimension is given by Voss [23] who identified the following: concept to service launch time, concept to prototype time, prototype to launch time, time to adopt new concept form outside the firm. For analyzed projects, it is important to monitor the duration of following phases [22]:
- Time needed for generation and evaluation of ideas and relevant external analysis

- Time from goals and strategy formulation to defining user requirements

- Time from defining user requirements to translating them into project requirements

- System development and testing time

- Time from defining user requirements to solution presentation

- Time needed for training the personnel of service provider and market test

- Time from goals formulation to launching

- Time from defining user requirements to launching

Table 1. Duration of phases and groups of activities in NSD projects

\begin{tabular}{|l|l|l|l|l|}
\hline & Project 1 & Project 2 & Project 3 & Project 4 \\
\hline $\begin{array}{l}\text { Project } \\
\text { phases }\end{array}$ & \multicolumn{4}{|l|}{ Duration (months) } \\
\hline i & 3 & 16 & 13 & 2 \\
\hline ii & 3 & 7 & 4 & 3 \\
\hline iii & 4 & 2 & 5 & 3 \\
\hline iv & 9 & 3 & 6 & 3 \\
\hline v & 13 & 5 & 11 & 6 \\
\hline vi & 1 & 1 & 2 & 1 \\
\hline vii & 20 & - & 21 & 11 \\
\hline viii & 17 & - & 20 & 6 \\
\hline
\end{tabular}

Time analysis showed the following: Generation and selection of ideas and external analysis (in terms of selected ideas) are interconnected phases which may take place in a period of a few months to over a year. The duration of these phases in analyzed projects depended on the degree of novelty and complexity of innovation. Longer duration of these phases was observed in the case of traffic cadastre, where service is a complete novelty that requires significant changes in current business practices. In the case of live betting longer duration came from special nature of the service, where imitation strategy was not possible, and where data protection and eliminating errors were of crucial importance. Certain amount of time has to pass since formulation of the project goals till definition of user requirements. In analyzed projects it was a period of three to seven months.

Defining user requirements and translating them into project requirements implied interactive work over a period of several months. Development of a system according to the requirements was done over a period of three months (cadastre and mobile marketing) to nine months (teletext). According to managers, the duration of these phases depended primarily 
on well prepared project requirements, and understanding of user requirements. In the case of teletext "certain requirements were not sufficiently well-defined" and the work was done "based on the assumptions" which later required a return to the previous stages for various changes.

It was noted that it has been 13 months from definition of user requirements to solution presentation past 13 months in case of teletext and 11 months in case of live betting. In case of the projects where the requirements were "very well defined" as it was traffic cadastre and mobile marketing the duration of same phases was only 5 to 6 months.

Staff training in service providing organization and market testing (if necessary) took place in short period in all projects - 1 to 2 months. From goals formulation to launch of new service passed 20 to 21 months (teletext and live betting), and only 11 months (mobile marketing).

The documentation analysis and conducted interviews enabled certain conclusions. The phases of defining user requirements and their translation into project requirements had approximately the same duration in all four cases. On the other side, the system development and testing had different duration in compared projects. It was to a smaller extent the result of project complexity, but rather the result of achieved level of understanding between participants who defined requirements with those who translated them. The above activities have an influence on project success. In certain cases (e.g. live betting) misunderstanding in development phases could bring great losses to service providing organization, financial and those related to credibility.

\section{CONCLUSION}

The knowledge and experience gained through innovation projects form a unique knowledge base of the organization that is a support for future innovations. The research presented in this paper resulted in indentifying general characteristics of innovation projects in services and more specific characteristics of project based on ICT development and implementation. Key participants in the cooperative ICT based NSD projects are big service providers and small firms with engineers working on ICT development and application. Inclusion of ICT experts in all project phases is necessary, as they provide valuable inputs for decision making.

Defining user requirements and translating them into project requirements may extend the duration of the entire project, as the corrective actions implemented in later development stages require additional time and resources. The knowledge, competence and understanding of all participants are determining factors.

From end-user perspective, commercialization phase could be considered as crucial for service adoption and success. However, the research has shown that key stages were the phases related to defining user requirements and translating them into project requirements. Fulfillment of user expectations depends on this phases. This phases imply many human interactions and any misunderstanding and wrong specification will have the influence on project time and costs. Determining the specifications depends on ability of employees more than on norms and standards, especially for development of completely new services.

From the perspective of management, research has shown that, although for each project there were responsible managers in service provider, as well as in ICT developing firms, management was not based on solid project management (focused on cost, time and quality). A degree of freedom and creativity was allowed, and the focus was on interactions and networking. Finding the right balance between project management with defined stages, time and resources on one side and creativity for innovation on the other will continue to be a challenge for researchers and practitioners in this field.

\section{REFERENCES}

[1] Levi Jaksic, M., Strateški menadžment tehnologije: Inovacije, menadžment i preduzetništvo, FON, Beograd, 2001.

[2] Jovanovic, P., Upravljanje projektom, FON, Beograd, 2006.

[3] Marinkovic, S., Levi Jaksic, M., Manić, B., Service innovations based on ICT implementation - roles of NSD participants, TTEM - Technics Technologies Education Management, 6, 2, p. 438-446, 2011.

[4] Shekar, A., An innovative model of service development: A process guide for service managers, The Innovation Journal: The Public Sector Innovation Journal, 12, 1, p. 2-20, 2007.

[5] Marinkovic, S., Menadzment inovacija u uslugama, Zaduzbina Andrejevic, Beograd, 2012.

[6] Haksever, C., Render, B., Russel, R. S, Murdic, R. G., Service Management and Operations, Pearson Education, 2000.

[7] Nijssen, E. J., Hillebrand, B., Vermeulen, P.A.M., Kemp, R. G. M., Exploring product and service innovation similarities and differences, International Journal of Research in Marketing 23, p. 241-251, 2006. 
[8] Smith, A. M., Fischbacher, M., New Service Development: a Stakeholder Perspective, European Journal of Marketing, 39, 9/10, p. 1025-1048, 2005.

[9] Bygstad, B., Lanestedt. G., ICT based service innovation - A challenge for project management, International Journal of Project Management, 27, 3, p. 234-242, 2009.

[10] Kuusisto, A., Riepula, M., Customer interaction in service innovation, Seldom intensive, but often decisive- Case studies in three business service sectors, Proceedings of the $9^{\text {th }}$ International CINet Conference - Radical Challenges in Innovation Management, Valencia, Spain, 2008.

[11] Gago, D., Rubalcaba, L., Innovation and ICT in service firms: towards a multidimensional approach for impact assessment, Journal of Evolutionary Economics, 17, 1, p. 25-44, 2007.

[12] Evangelista, P., Sweeney, E., Technology usage in the supply chain: the case of small 3PLs, Te International Journal of Logistic Management, 17, 1, p. 55-74, 2006.

[13] Schilling, M. A., Strategic Management of Technological Innovation, McGraw-Hill, New York, 2005.

[14] Van Riel, A. C. R., Lievens, A., New Service Development in High Tech Sectors - a Decision Making Perspective, International Journal of Service Industry Management, 15, 1, p. 72-101, 2004.

[15] Cooper, R. G., Stage-gate systems: a new tool for managing new products, Business Horizons, 33, 3, p. 44-54, 1990.
[16] Howe, V., Mathieu, R.G., Parker, J., Supporting new product development with the Internet, Industrial Management \& Data Systems, 100, 6, p. 277284, 2000.

[17] Levi Jaksic, M, Marinkovic, S., Obradovic, J., Menadžment inovacionih performansi organizacije, Tehnika, 4, p. 1-6, 2007.

[18] Candi, M., Van den Ende, J., Gemser, G., Organizing innovation projects under technological turbulence, Technovation, 33, 4, p. 133-141, 2013.

[19] Menor, L.J., Roth, A.V., New service development competence in retail banking: Construct development and measurement validation, Journal of operations management, 25, p. 825-846, 2007.

[20] Christie, M., Rowe, P., Perry, C., Chamard, J., Implementation of realism in Case Study Research Methodology, International Council for Small Business, Annual Conference, Brisbane, 2000.

[21] Eisenhardt, K.M., Building theories from case study research, Academy of Management Review, 14, 4, p. 532-550, 1989.

[22] Marinkovic, S., Razvoj modela menadžmenta inovacija u uslugama, University of Belgrade, Faculty of Organizational Sciences, PhD dissertation, December 2010.

[23] Johne, A., Storey, C., New service development: a review of literature and annotated bibliography, European Journal of Marketing, 32, 3/4, p. 184-251, 1998.

\section{REZIME}

\section{MENADŽMENT INOVACIONIH PROJEKATA U USLUGAMA ZASNOVANIH NA IKT}

Projekti inovacija usluga kod kojih se novina zasniva na uvođenju savremenih IKT obično podrazumevaju kooperaciju između različitih učesnika i organizacija. Prepoznajući specifičnu prirodu inovacionih projekata u uslugama, ovaj rad predstavlja rezultate istraživanja metodom studije slučaja koje je obuhvatilo četiri inovaciona projekta sprovedena u Srbiji. Upoređene su i analizirane specifične karakteristike i trajanje faza posmatranih projekata. Simultanost u sprovođenju određenih faza uočena je u svim projektima. Sa aspekta menadžmenta, kao najznačanije faze označene su definisanje korisničkih zahteva i njihovo prevođenje u projektne zahteve. Potvrđeno je da je kod inovacionih projekata fokus projektnih menadžera na interakcijama $i$ umrě̌avanju, sa značajnim stepenom slobode $i$ kreativnosti.

Ključne reči: razvoj novih usluga, inovacioni projekat, informaciona i komunikaciona tehnologija 